\title{
The Effect of Teaching Picture-books on Elementary EFL Learners' Vocabulary Learning
}

\author{
Arash Hashemifardnia \\ PhD Student, Department of English, Faculty of Humanities, Shahrekord Branch, \\ Islamic Azad University, Shahrekord, Iran \\ e-mail: Sadi6675@gmail.com \\ Ehsan Namaziandost \\ PhD Student, Department of English, Faculty of Humanities, Shahrekord Branch, \\ Islamic Azad University, Shahrekord, Iran \\ e-mail:e.namazi75@yahoo.com \\ Fariba Rahimi Esfahani \\ Assistant Professor, Department of English, Faculty of Humanities, Shahrekord \\ Branch, Islamic Azad University, Shahrekord, Iran \\ e-mail: Rahimi_fariba@yahoo.com
}

\begin{abstract}
Regarding the attractiveness of picture books, this study examined the effects of teaching picture books on vocabulary learning of 40 Iranian elementary students. The participants were randomly assigned to two groups of 20; one experimental and one control. Then, their knowledge of vocabulary was assessed through administering a researcher-made vocabulary pre-test. After that, the researchers started to teach the experimental group through teaching picture-book of Starters Word List Picture Book. The words were taught to the students and they were required to match each word with its picture. The control group was instructed through their school textbook (Prospect One). The words were taught without their pictures; the words were read and simultaneously the students were wanted to repeat them and write their Persian equivalents. After the instruction ended, a vocabulary post-test was given to determine the effects of the treatment on the students' vocabulary learning. The results of paired and independent samples t-tests indicated that the experimental group outperformed the control group on the post-
\end{abstract}


test. It was also revealed that teaching through picture books resulted in better vocabulary learning.

Keywords: Picture books, Vocabulary learning, elementary students

\section{INTRODUCTION}

Picture books can serve as a chief part of relevant, challenging, integrative, and exploratory curriculum for any content area. According to Hurst (1997), picture books have considerable role in every classroom. The wonderful combination of visual and textual story that picture books offer is a valuable literary experience. By picture books, we mean books consisting of text and pictures, "in which the story depends on the interaction between written text and image and where both have been created with a conscious aesthetic intention" (Arizpe \& Styles, 2003, p. 22).

Brown (2004) asserts that using a variation of media will increase the chance that the learners will recall better what they learn in developing the performance of skill they are expected to improve. There are many varieties of teaching media that can be used to deliver the lesson and one of them is picture. Harmer (2001) states that picture is one of the variabilities of teaching supports which is used to describe language meaning structure, to employ learners in a topic, or as the base of an entire activity.

According to Matulka (2008), a good picture series in a story links the reader to the pictures and generates the implication of the pictures. Story and pictures work together to push the story onward. Lee (2015) points out that students enjoyed picture books and felt they had made development in their English language ability, especially in terms of motivation and confidence. The use of picture book that has imaginative characters such as comic is more efficient to teach reading than those of general texts and pictures (Roozafzai, 2012).

Through teaching picture books, we can help EFL learners to learn English vocabulary more easily. Vocabulary knowledge is often viewed as a critical tool for second language learners because a limited vocabulary in a second language impedes successful communication. Underscoring the importance of vocabulary acquisition, Schmitt (2000) emphasizes that "lexical knowledge is central to communicative competence and to the acquisition of a second language" (p. 55).

Read (2001) mentions that vocabulary learning is considered as an unavoidable scope of language teaching by ELT researchers in which words are the basic building blocks of language, the units of meaning from which larger structures such as sentences, paragraphs, and whole texts are formed. Decarrico (2001) mentions, "vocabulary acquisition is central to language acquisition, whether the language is first, second, or foreign" (p. 285). According to Zhihong (2000), "vocabulary is a component of language that maintains all of information about meaning and using word in language" (p. 23). 


\section{LITERATURE REVIEW}

One useful technique to teach vocabulary is using picture books. Bader (1976) defined picture book as a text, illustrations, total design, an item of manufacture and a commercial product, a social, cultural, historical document; and foremost an experience for a child. As an art form, it hinges on the interdependence of pictures and words, on the simultaneous display of two facing pages, and on the drama of turning the page. Picture books can be seen "as a kind of miniature ecosystem" (Lewis, 2001, p. 46) which suggests that "the words and the pictures in picture books act upon each other reciprocally, each one becoming the environment within which the other lives and thrives" (Lewis, 2001, p. 48). According to Nikolajeva and Scott (2006), picture books give the impression of being an exciting, stimulating and vibrant branch of children's literature.

Picture books can serve as a scaffold for adolescents in a number of ways. Pictures books can be used to scaffold learning of complex concepts, bridging gaps between personal experiences and texts, making connections between students' existing literacy resources and the ones necessary for various disciplines (National Council of Teachers of English, 2006). Using picture books in middle school and high school classrooms can enhance all content learning (Tiedt, 2000). Picture books can present complex ideas, making content learning easier at multiple levels (Henry \& Simpson, 2001). They can help students visualize the place and time of historical events and faraway lands (McGlinn \& McGlinn, 2004). Picture books engage reluctant readers, motivating them to tackle reading/writing assignments and much-needed reading practice (Moje, Young, Readence, \& Moore, 2000).

Picture books can provide children with free space of imagination and creation, allowing them to create multidimensional meaning of the text through the reading process. In addition, they have less words and more space for children's imagination to expand (Lin, 2007). The significance of picture books to children is that to introduce fine literary works and different culture to children. And using picture books as a teaching tool can be one of the interactive methods in teaching children English (Lin, 2007).

When we read a picture book, we look at the pictures and we read the words and our eyes move back and forth between the two as we piece together the meaning of the text. Lewis (2001) refer to picture book text is an "interweaving of words and pictures" (Lewis 2001, p. 33). The words may tell us the exact same story as we can "read" from the pictures. The words may draw our attention to details in the picture and the rest is up to our imagination. It all depends upon how word and picture interact. The combination of the two levels of communication, the visual and the verbal, is what makes the picture book unique. Based on this we may say that picture books communicate by means of two separate sets of signs, the iconic and the conventional.

Nikolajeva and Scott (2006) defined iconic signs as "those in which the signifier and the signified are related by common qualities; that is, where the sign is a direct representation of its signified" (Nikolajeva \& Scott 2006, p. 1). This means a picture of a printer on a computer's command menu is an icon; a direct representation of the printer. In most cases, we do not need special knowledge to 
understand a simple icon. Conventional signs, on the other hand, have no direct relationship with the object signified. The word print in a menu only conveys a meaning if we possess the code; that is, we must know what the letters stand for. Nikolajeva and Scott (2006) defined it as; conventional signs are based on an agreement among the bearers of a particular language, both the spoken language and the communicators, such as gestures, dress code, or emblems (Nikolajeva \& Scott 2006). That means conventional signs do not carry any meaning for those outside the given community. Both iconic and conventional signs have existed in human culture though, from its beginning, and have given rise to the two parallel types of communication we today know as the visual and the verbal.

The pictures in picture books are complex iconic signs, and words in picture books are complex conventional signs. However, the basic relationship between the two levels is the same. The function of pictures, the iconic signs, is to describe and represent while the function of words, the conventional signs, is primarily to narrate. The conventional signs are often linear, while iconic signs are nonlinear and do not give the reader direct instruction about how to read them. The tension between the two functions creates unlimited possibilities for interaction between word and image in a picture book (Grundvig, 2012). Whichever we start with the verbal or the visual when we "read" a picture book, expectations are created. The reader turns from verbal to visual and back again, expanding their understanding. Each new rereading of either words or pictures creates better prerequisites for an adequate interpretation of the whole. Presumably, children know this by intuition when they demand that the same book be read aloud to them over and over again. Actually, they do not read the same book; they go more and more deeply into its meaning. Perhaps adults have lost the ability to read picture books in this way, because they ignore the whole and regard the pictures as merely decorative. This is closely tied to the dominant position of verbal, especially written, communication in our society (Grundvig, 2012).

However, adults may read the same book twice, and experience new details being revealed as they tend to pay closer attention to the words and possible interpretations the second time around, already knowing the outcome. This brings us to reader-response theory. Reader-response theory, with its central notion of textual gaps, is also valuable in approaching picture book dynamics (Nikolajeva \& Scott 2006). We find both word and picture to leave room for the "readers" to fill with their previous knowledge, experience, and expectations, and we may find infinite possibilities for word - picture interaction. Both verbal and visual texts have their own gaps and words and pictures might fill each other's gaps, wholly or partially. Having said that, they can also leave gaps for the "readers" to fill; meaning both words and pictures can be evocative in their own ways as well as independent of each other.

Regarding the effects of picture books on English language learning several empirical studies have been conducted, for example, Sun (2015) studied 27 young adult EFL learners' engagement in five picture-book lessons sheds light on the influence of non-vocabulary-enhancement activities on vocabulary growth. Each lesson in her study consisted of three stages: warm-up, individual picture-book reading, and a collaborative post-reading activity that encouraged learners to interact 
with text, illustrations, and peers to construct and reflect on story meaning. She found that the text interactions and group discussions facilitated students' understanding of unfamiliar words presented in the text. Activities that involved predicting for meaning and reflective journal writing, which required good comprehension of the text, provided opportunities for students to collaboratively figure out the word meanings, which incidentally contributed to their vocabulary learning. In this way, vocabulary learning could take place naturally in activities where the learning focus is not to help learners acquire new words, but to facilitate their understandings of the message behind the story. Most importantly, according to Sun, this kind of activity created a space in which learning was enjoyable and active, which is essential for language learning but rarely seen in a typical EFL class in Taiwan. While Sun's qualitative data revealed the value of these output activities for word learning, further, more robust verification is needed to show the degree to which words can be learned from this kind of supplementary activity.

In another study, Sun (2016) investigated the effects of three instructional modes: picture-book reading-only (PRO), picture-book reading plus vocabulary instruction (PRVI), and picture-book reading plus reading-based collaborative output activity (PRCOA) on young adult EFL (English as a foreign language) learners' vocabulary acquisition and retention. Eighty Taiwanese university students with low to intermediate level English proficiency from three English reading classes participated in each of the three modes once during three weekly 100-minute sessions. Vocabulary knowledge was tested through two post-tests using a modified Vocabulary Knowledge Scale: immediately after each instructional mode to measure students' vocabulary acquisition, and one month later to measure their word retention. The results showed that the PRVI mode was the most helpful for immediate word learning. However, the PRCOA mode was the most effective for word retention, and most conducive to bettering students' productive knowledge in both acquisition and retention. This study suggested that explicit learning from vocabulary instruction that directs students' attention to the words to be learned did not guarantee greater vocabulary gains than incidental learning where new words can be learned as by-products of classroom collaborative output activities. Without trying to memorize words, students learned vocabulary through mental investment in group discussions and generative activities, leading to their mastery of productive word knowledge.

The reviewed literature indicates that teaching through picture books has not received enough attention it deserves. In other words, rare studies, it any, have been conducted to examine the effects of picture-books in Iranian educational context. Therefore, this study made an attempt to cover this gap.

\section{OBJECTIVES OF THE STUDY}

Teaching via picture books is of great importance due to their attractive features. Pictures containing in the books increase motivation of the students and engage them in learning as Paquette (2007) asserts that picture books provide a natural avenue to motivate and encourage students to learn English language. 
Regarding the importance of picture-books, this study aimed to inspect the effect teaching picture-books on elementary EFL learners' vocabulary learning.

\section{RESEARCH QUESTION AND NULL HYPOTHESIS}

The following research question was answered in this research:

RQ. Does teaching picture-books have any significant effect on Iranian elementary EFL learners' vocabulary learning?

The following null hypotheses was suggested in this study:

HO. Teaching picture-books does not have any significant effect on Iranian elementary EFL learners' vocabulary learning.

\section{RESEARCH METHODS}

\subsection{Participants}

Deciding to carry out this work, the researchers selected 40 participants out of 60 Iranian students based on the results of Oxford Quick Placement Test (OQPT). The selected participants were all at the elementary level. They were 12 to 14 years old and their gender was male. The participants were randomly divided into two equal groups of 20; one experimental and one control.

\subsection{Instruments}

The OQPT was the first instrument used in this study to make the participants homogenous. Based on the results of this test, 40 students were at the elementary level and were chosen as the target population of the current research.

The second instrument utilized in this research was a researcher-made vocabulary pre-test which was designed based on the students' course book. It was made up of 30 objective items including matching, multiple-choice, and true or false items. After the test was constructed, the researchers validated it by a group of English experts, besides, they calculated the reliability indexes of the test through using KR-21 formula ( $\mathrm{r}=0.822$ ). In addition, the researchers piloted the pre-test on another smaller scale to test how possible the design is in reality. For example, are the study resources adequate, including time, finances, and materials? Are there are any other logistical problems that need to be addressed?

The third instrument of the current research was a vocabulary post-test. In fact, the post-test was the modified form of the pre-test with nuanced differences. The researchers changed the order of options and questions so as to hinder the students to recall the pre-test answers.

\subsection{Data Collection Procedure}

After dividing the students into control and experimental groups, the researchers administered a vocabulary pre-test to measure the current vocabulary knowledge of the students. Then after, the researchers started to teach each group. The experimental group received the treatment through using picture-book (Starters Word List Picture Book). It should be noted that all students were provided with picture-book. Their picture-book was full of pictures and each word had its own picture. Before starting to teach the words, the participants were required to look at 
the words and infer their meanings by pictorial clues. Then, the researcher taught each word and wanted the students to match each word with its picture.

The control group was instructed through their school textbook (Prospect One)- a book with very few pictures. The words were taught without their pictures; the researcher read each word and simultaneously the students repeat that word. The Persian equivalent of each word was provided for this group to capture the meaning of the target word. This process continued in seven sessions. After the treatment ended, a vocabulary post-test was administered to assess the impacts of the instruction on the students' vocabulary learning.

\subsection{Data Analysis}

After collecting the sufficient data, they were analyzed through using SPSS software, version 22. Firstly, descriptive statistics were calculated. Secondly, paired and independent samples t-tests were used to determine the impacts of the treatment on the students' vocabulary learning.

\section{RESULTS}

In order to analyze the gathered data, the SPSS software, version 22 software was used.

Table 1: Group Statistics (Pre and Post-tests of Both Groups)

\begin{tabular}{llllrr}
\hline & Groups & N & Mean & $\begin{array}{c}\text { Std. } \\
\text { Deviation }\end{array}$ & $\begin{array}{c}\text { Std. Error } \\
\text { Mean }\end{array}$ \\
\hline Pretest & Experimental group & 20 & 13.6000 & 2.89100 & .64645 \\
\cline { 2 - 6 } & Control group & 20 & 13.5000 & 2.76253 & .61772 \\
\hline Posttest & Experimental group & 20 & 18.3500 & 7.95563 & 1.77893 \\
\cline { 2 - 6 } & Control group & 20 & 13.6500 & 2.71981 & .60817 \\
\hline
\end{tabular}

As the table above shows, the mean scores of the experimental group on the pre and post-tests are 13.60 and 18.35 respectively. And the control groups' mean scores on the pre and post-tests are 13.50 and 13.65. To see if the difference between the groups is significant, independent samples t-test was used (Table 2).

Table 2: Independent Samples T-test (Pre and Post-tests of Both Groups)

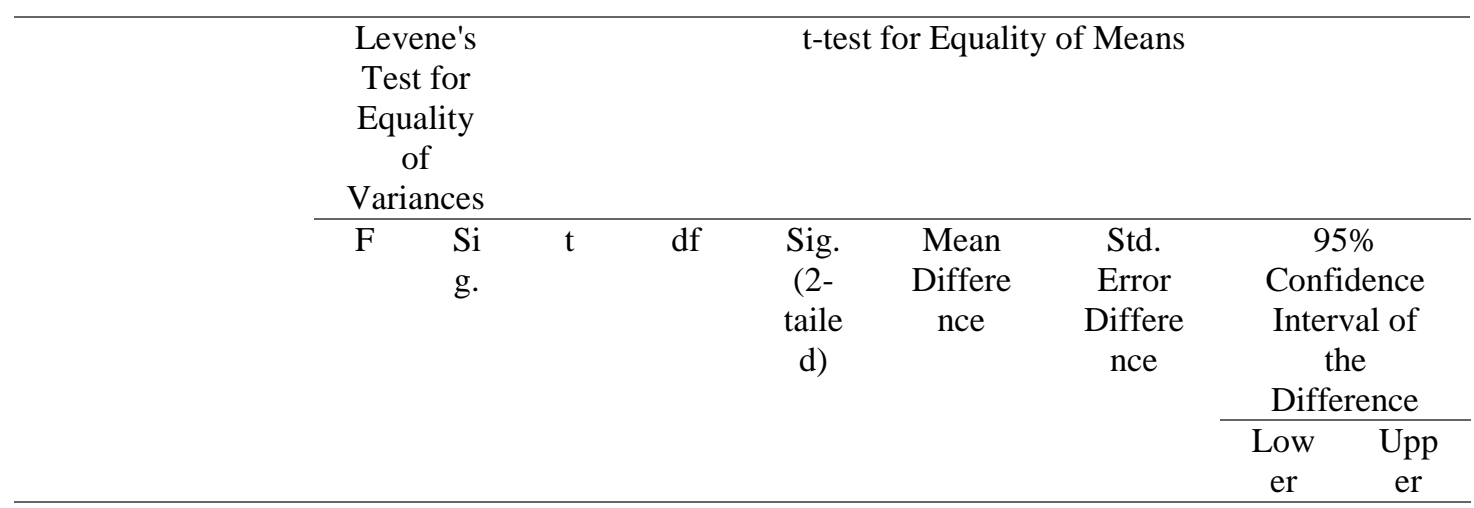




\begin{tabular}{|c|c|c|c|c|c|c|c|c|c|c|}
\hline \multirow[t]{2}{*}{$\begin{array}{l}\text { Prete } \\
\text { st }\end{array}$} & $\begin{array}{l}\text { Equal } \\
\text { varian } \\
\text { ces } \\
\text { assum } \\
\text { es }\end{array}$ & $\begin{array}{r}.16 \\
6\end{array}$ & $\begin{array}{r}.68 \\
6\end{array}$ & $\begin{array}{r}.11 \\
2\end{array}$ & 38 & .912 & .10 & .89413 & $\begin{array}{r}- \\
1.71 \\
0\end{array}$ & $\begin{array}{r}1.91 \\
0\end{array}$ \\
\hline & $\begin{array}{l}\text { Equal } \\
\text { varian } \\
\text { ces not } \\
\text { assum } \\
\text { es }\end{array}$ & & & $\begin{array}{r}.11 \\
2\end{array}$ & $\begin{array}{r}37.9 \\
22\end{array}$ & .912 & .10 & .89413 & $\begin{array}{r}- \\
1.71 \\
0\end{array}$ & $\begin{array}{r}1.91 \\
0\end{array}$ \\
\hline \multirow[t]{2}{*}{$\begin{array}{l}\text { Postt } \\
\text { est }\end{array}$} & $\begin{array}{l}\text { Equal } \\
\text { varian } \\
\text { ces } \\
\text { assum } \\
\text { es }\end{array}$ & $\begin{array}{r}.98 \\
4\end{array}$ & $\begin{array}{r}.32 \\
7\end{array}$ & 2.5 & 38 & .017 & 4.70 & 1.88002 & .894 & $\begin{array}{r}8.50 \\
5\end{array}$ \\
\hline & $\begin{array}{l}\text { Equal } \\
\text { varian } \\
\text { ces not } \\
\text { assum } \\
\text { es }\end{array}$ & & & 2.5 & $\begin{array}{r}23.3 \\
8\end{array}$ & .020 & 4.70 & 1.88002 & .814 & $\begin{array}{r}8.58 \\
5\end{array}$ \\
\hline
\end{tabular}

In Table 2, an independent samples t-test was used to show the scores of both groups on the pre and post-test. Since Sig (.912) is greater than 0.05, the difference between the pre-tests of both groups is not significant at $(\mathrm{p}<0.05)$. But, the difference between the post-tests of both groups is significant at $(\mathrm{p}<0.05)$, since Sig (.017) is less than 0.05 .

Table 3: Paired Samples T-test (Pre and Post-tests of each Groups)

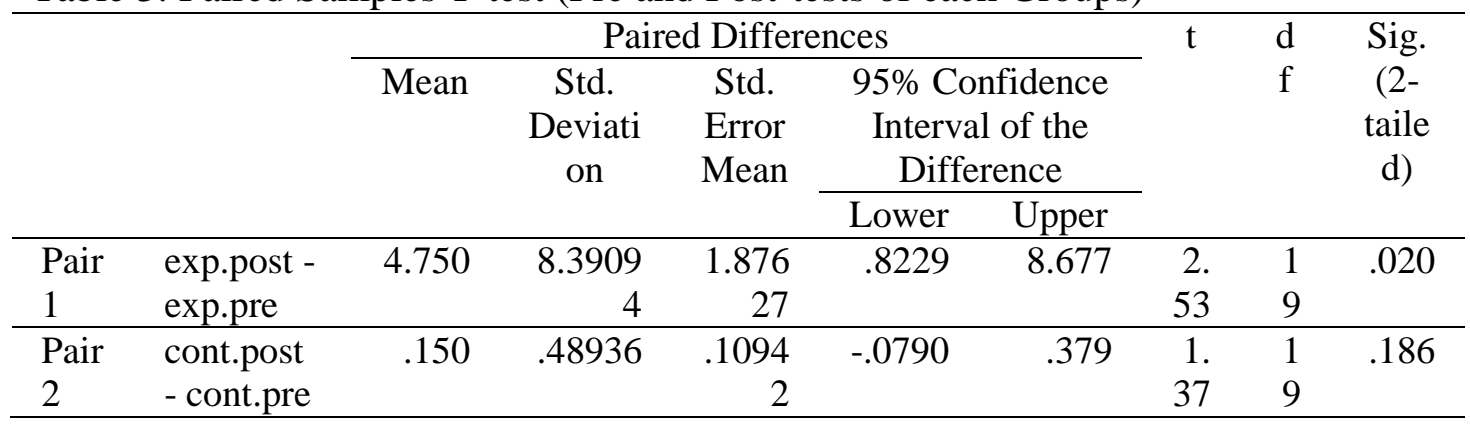

In the above table, paired samples t-test is used to compare the pre and posttests of each group. Since Sig (.20) is less than 0.05, the difference between the pretest and post-test of the experimental group is significant. Since Sig (.186) is greater than 0.05 , the difference between the pre-test and post-test of the control group is not significant. It can be concluded that the treatment made an outstanding contribution to the students' vocabulary learning.

\section{DISCUSSION}

The obtained results indicated that teaching picture-books have significant effect on Iranian EFL learners' vocabulary learning. The findings showed that the experimental group who received the treatment through picture-book did 
significantly better than the control group on the post-test. After administering the post-test, it was proved that students learned some English vocabulary through using picture book. The researchers noticed that clear, colorful and eyes-catching pictures can take the students' attention to focus and learn the vocabulary words.

Visual materials like pictures have an important role for improving knowledge and leaning process as Mayer and Sims (1994) asserted that words are learned better through visual elements such as pictures or real objects because the use of pictures is easier and more effective and also images are useful for learning process. As a result, they are used by teachers for better learning.

Similarly, Hurst (1997) said that picture books have important role in every classroom because the wonderful combination of visual and textual story that picture books offer was a valuable literary experience for the students. Picture books can provide the scaffolding that traditional text books and higher-level mentor texts cannot provide to upper level ELL and special education students.

The illustrations present in the picture books can aid all emerging readers by providing them with "a bridge to content that might otherwise be missed by allowing pictures to fill in the blanks of unfamiliar vocabulary" (Wilkins, Sheffield, Ford, \& Cruz, 2008, p. 177). Picture books can be seen "as a kind of miniature ecosystem" (Lewis 2001, p. 46) which suggests that the words and the pictures in picture books act upon each other reciprocally, each one becoming the environment within which the other lives and thrives (Lewis, 2001).

In this study, picture books provided children with rich vocabulary and support known and unknown words. Picture books give the impression of being an exciting, stimulating and vibrant branch of children's literature. Picture books are multifaceted and can enhance motivation in the learning process and can be used to integrate aspects of multiple curricula for intermediate and secondary students (Massey, 2015). For example, Premont, Young, Wilcox, Dean, and Morrison (2017) explored the used use of picture books in a high school setting to improve students' word choice, sentence fluency, and conventions in narrative writing. The tenth-grade student participants in Premont et al.'s study used the "picture books as coaches" (Premont et al., 2017). The results shared a significant increase in their performance and in their writing skills after the implementation of picture books into their curriculum.

The brevity and attractiveness of picture books were the features that made picture books so valuable to Iranian EFL learners. Picture books can be used to begin a new topic, revisit old topics, connect with other books, engage with higher level thinking and questioning, talk about difficult topics, and introduce emergent readers and writers to literacy as well as the reading and writing process. Picture books benefit each subject area and are a necessity in the early childhood classroom (Heinsbergen, 2013). Every classroom and library should be stocked with a large variety of picture books to benefit not only the subject areas, but also the diverse students in today's classes. 


\section{CONCLUSION}

In sum, it can be concluded that our study provided evidence for giving picture book a significant place in the EFL learners' curriculum for supporting the students' learning English development. We witnessed that the students developed their vocabulary knowledge through engaging in picture books. The findings revealed that picture books in Iranian EFL English classrooms can lead to increased vocabulary knowledge as a result of the close relations of the written and the visual text.

Picture books are a popular way of teaching and learning, and they must be chosen very carefully. Picture books can be suitable both for the teachers to teach and for the learners to learn. They need to be visible and eye-catching, especially if teachers want to teach them to the elementary students. When educators skillfully select and embed picture books into their curriculum, picture books can help an older students' construction of knowledge, motivate them to read, and help them solidify literary concepts that might not have been able to understand without the assistance of the picture books (Wilkins, Sheffield, Ford, \& Cruz, 2008).

Future studies are suggested to include more training sessions to gain more reliable data to reach more valid results. Upcoming studies need to determine if the treatment is equally effective in diverse populations and other geographical locations. The other advice to the further studies is to include more participants to get richer and more reliable findings. In addition, in studies with the similar topic both female and male students are recommended to be involved. Moreover, it is suggested that next studies examine the effects of picture-books on other skills and sub-skills of English.

\section{REFERENCES}

Arizpe, E., \& Styles, M. (2003). Children reading pictures: Interpreting visual texts. London: Routledge/Falmer.

Bader, B. (1976). American picture books from Noah's ark to the beast within. Macmillan Pub Co.

Brown, H. (2004). Language assessment: Principles and classroom practices. New York: Pearson/Longman.

Decarrico, J.S. (2001). Vocabulary learning and teaching. Celce-Murcia, M. (ed.). Teaching English as a second or foreign language, pp. 285-299. Boston: Heinle \& Heinle.

Grundvig, V. (2012). Can picture books in the English classroom lead to increased reading comprehension? Educational Leadership, 7(4), 32-39.

Harmer, J. (2001). The practice of English language teaching (4th ed.). UK: Pearson Longman.

Heinsbergen, N. A. (2013). The positive effects of picture books providing acceptance of diversity in social studies and increased literacy in early childhood education. Education and Human Development Master's Theses. 305. http://digitalcommons.brockport.edu/ehd_theses/305.

Henry, R., Simpson, C. (2001). Picture books and older readers: A match made in heaven. Teacher Librarian, 28(3), 25-30. 
Hurst, C. (1997). Featured subject: Picture books in the classroom, PreK-9. Carolhurst.com. Retrieved 18 January 2018, from http://www.carolhurst.com/newsletters/21bnewsletters.html

Lee, H. (2015). Using picture books in EFL college reading classrooms. Reading Matrix: An International Online Journal, 15(1), 66-77.

Lewis, D. (2001). Reading contemporary picture books. Picturing text. London/ New York, Routledge/ Falmer.

Lin, W.S. (2007). How to read picture books and tell the stories for children Discussing possible applications of picture books on cultivation. Retrieved January, 7, 2018 from http://www.tncsec.gov.tw/upload/j01/1973.doc

Massey, S. (2015). The Multidimensionality of children's picture books for upper grades. English Journal, 104 (5), 45-58.

Matulka, D. I. (2008). A picture book primer: Understanding and using picture books. Greenwood Publishing Group.

Mayer, R. E., \& Sims, V. (1994). For whom is a picture worth a thousand words? Extensions of a dual-coding theory of multimedia learning. Journal of Educational Technology, 86, 389-401.

McGlinn, J.M., \& McGlinn, M.M. (2004). Opening their eyes; Picture books in High school social studies classes. The Journal of the Children's Literature and Reading Special Interest Group, 22(2) $20-28$.

Moje, E.B., Young, J.P., Readence, J.E., \& Moore, D.W. (2000). Reinventing adolescent literacy for new times: Perennial and millennial issues. Journal of Adolescent and Adult Literacy, 43, 400-410.

National Council of Teachers of English (2006). Adolescent and young adult literacy: Policy statement. Retrieved February 2006 from www.ncte.org/edpolicy/literacy.

Nikolajeva, M., \& Scott, C. (2006). How picture books work. New York: Routledge.

Paquette, K. R. (2007). Encouraging primary students"' writing through children's literature. Early Childhood Education Journal, 35 (2), 155-165.

Premont, D. W., Young, T. A., Wilcox, B., Dean, D., \& Morrison, T. G. (2017). Picture books as mentor texts for 10th grade struggling writers. Literacy Research and Instruction, 56(4), 290-310.

Read, J. (2001). Assessing vocabulary. Cambridge: Cambridge University Press.

Roozafzai, Z. (2012). The role of comic reading materials in enhancing the ability to read in EFL. Journal on English Language Teaching, 2(3), 7-15.

Schmitt, N. (2000). Vocabulary in language teaching. Cambridge: Cambridge University Press.

Sun, C.H. (2015). The three little wolves go to college: A picture book lesson for young adult EFL learners. Journal of Adolescent and Adult Literacy, 59, 183195.

Sun, C.H. (2016). The value of picture-book reading-based collaborative output activities for vocabulary retention. Language Teaching Research, 21(1) 96117.

Tiedt, I.M. (2000). Teaching with picture books in the middle school. Newark, DE: International Reading Association. 
The Effect of Teaching Picture-books on Elementary EFL Learners' Vocabulary

Wilkins, K. H., Sheffield, C. C., Ford, M. B., \& Cruz, B. C. (2008). Images of struggle and triumph: Using picture books to teach about civil rights in the secondary classroom. Social Education, 72(4), 177-180.

Zhihong, Y. (2000). Learning words. English Teaching Forum, 3(8), 123-148. 